\title{
Daily Winners and Losers in the Korean Stock Market
}

\author{
Jangkoo Kang, Professor, KAIST
}

Jaesun Yun*, Ph.D. Candidate, KAIST

\begin{abstract}
$<$ Abstract $>$
In their working paper, Kumar, Ruenzi, and Ungeheuer (KRU) document that stocks ranked as daily winners or losers in the previous month underperform unranked stocks during the month after the ranking. KRU explain that the ranked stocks experience a large increase in investor attention, which leads to temporary overpricing and subsequent underperformance. Following KRU, we investigate whether the same effect exists in the Korean stock market and find a robust daily winners and losers effect. First, stocks that were both daily winners and losers in a given month underperform those that were neither daily winners nor losers during the following months. Second, stocks that were never a daily winner or loser during the previous month do not exhibit the idiosyncratic volatility puzzle or the MAX effect. Moreover, the underperformance of ranked stocks is robust after controlling for the idiosyncratic volatility and the MAX effect. We suggest that the overpricing caused by excessive attention to daily winners and losers may be the main driver of the idiosyncratic volatility puzzle and the MAX effect. Lastly, we find that retail investors buy daily winners and losers, while both institutional investors and foreign investors decrease trades in the ranked stocks.
\end{abstract}

Keywords: Investor Attention; Retail Investors; Idiosyncratic Volatility Puzzle; Stock Rankings; MAX Effect

JEL Classification: G11, G12, G14

* Corresponding Author. Address: KAIST College of Business, 85 Hoegi-ro, Dongdaemun-Gu, Seoul, Korea 02455; E-mail: yjs16@kaist.ac.kr; Tel: +82-2-958-3693.

Received: March 27, 2020; Accepted: June 8, 2020 


\title{
한국 주식시장의 일간 승자/패자 효과
}

\author{
강 장 구 (KAIST 교수) \\ 윤 재 선 (KAIST 박사과정)*
}

\begin{abstract}
일간 수익률 상위나 하위를 기록한 종목들은 투자자들의 많은 관심을 받게 된다. Kumar, Ruenzi와 Ungeheuer는 미국 주식시장에서 이러한 종목들이 과대평가되고, 따라서 미래에 낮은 수익을 얻는 것을 최근 연구에서 보고하고 있다. 본 연구는 한국 주식시장에서도 이와 같은 일간 승자/패자 효과가 나타 남을 보인다. 일간 승자와 패자였던 종목을 매도하고, 한번도 승자나 패자였던 적이 없는 종목을 매수 하는 전략은 유의한 양의 수익을 얻는다. 또한, 일간 승자/패자 효과가 고유변동성 이상현상이나 MAX 효과에 대한 새로운 설명을 제시함을 보인다. 한번도 승자나 패자였던 적이 없는 종목에서는 고유변동성 이상현상과 MAX 효과가 사라지고, 고유변동성 이상현상이나 MAX 효과를 통제한 후에도 일간 승자/ 패자 효과는 여전히 존재하는 것으로 나타났다. 이와 같은 결과는 일간 승자/패자 효과가 고유변동성 이상현상이나 MAX 효과를 일으키는 근원임을 시사한다. 마지막으로, 일간 승자종목과 패자종목을 주로 거래하는 투자자는 개인투자자이며, 기관투자자나 외국인 투자자는 해당 종목에 대한 거래를 유의하게 줄이는 것을 보인다.
\end{abstract}

핵심 단어 : 투자자 관심(Investor attention), 개인투자자, 고유변동성 이상현상, 수익률 순위, MAX 효과

JEL 분류기호: G11, G12, G14

\footnotetext{
* 연락담당 저자. 주소: 서울특별시 동대문구 회기로 85 KAIST 경영대학, 02455; E-mail: yjs16@kaist.ac.kr; Tel: 02-958-3693.
} 


\section{1. 서론}

본 연구는 Kumar et al.(2020)(이하 KRU)가 미국시장에서 보고한 일간 승자/패자 효과가 한국시장에서도 나타나는지를 살펴 본다. 일간 승자/패자 효과란, 일간 수익률 상위나 하위를 기록한 종목이 그 다음 달에 낮은 수익을 내는 것을 말한다. KRU는 미국 주식시장에서 그와 같은 현상이 나타나는 것을 보고하며, 이는 투자자들의 한정된 관심이 일간 승자와 패자에 과도하게 쏠리게 되면서 시장에서 과대평가되고, 따라서 미래 수익률이 낮게 나타 난다고 주장한다.

미국시장과 마찬가지로 한국 주식시장에서도 일간 수익률이 아주 높거나 낮은 주식들은 신문 기사나 온라인에 많이 노출되는 경향이 있다. 경제 신문에서는 장이 마감되면 시황을 보고하며 하루 중 급등하거나 급락한 종목들에 대해서 브리핑을 하는데, 그런 기사들이 투자자들에게 다량 노출되면서 해당 종목들이 많은 관심을 받게 된다. 이와 같은 관심은 거래로 이어질 가능성이 높아지는데, 개인투자자들이 공매가 제한된 상황에서 이들 종목에 과도한 관심을 갖게 되면 해당 종목들이 시장에서 고평가 되기 쉽다. 과도한 관심으로 고평가된 일간 급등/급락 종목들은 궁극적으로는 다시 정상 가격으로 회귀하게 되는데 이 과정에서 낮은 수익을 얻게 된다. $\mathrm{KRU}$ 는 실제로 이와 같이 일간 승자/패자 주식에 대한 과도한 관심이 미국주식시장에서 미래의 낮은 수익률을 야기한다는 것을 보인다.

$\mathrm{KRU}$ 는 이런 일간 승자/패자 효과가 고유변동성 이상현상이나 MAX 효과와 같은 복권 성향 주식(lottery-like stock)과 관련된 효과들로는 설명되지 않고, 반대로 일간 승자/패자 효과가 고유변동성 이상현상이나 MAX 효과를 설명할 수 있다고 주장한다. 또한, 잘 알려져 있는 고유변동성 이상현상이나 MAX 효과가 전체 주식 중 아주 일부인 일간 승자/패자 종목을 제외한 대부분의 종목들에서는 나타나지 않는 것을 보이면서, 높은 고유변동성을 갖는 주식이 낮은 미래 수익을 얻거나 MAX가 큰 종목들이 미래 낮은 수익률을 갖는 것이 개인투자자들의 극단적인 관심을 받는 소수의 종목들이 고평가 되는 현상에서 기인한다고 설명하고 있다.

본 연구는 $\mathrm{KRU}$ 의 결과가 한국의 주식시장에서도 성립하는지 살펴본다. 주요 결과는 다음과 같다. 첫째, 한국 시장에서도 유의한 일간 승자/패자 효과가 나타난다. 일간 승자/ 패자였던 경우가 없었던 종목들을 매수하고, 일간 승자/패자 종목을 매도하는 포트폴리오를 구성하면, 유의한 양의 수익을 얻으며(월 평균 $2.30 \%$ ), 이 프리미엄은 기존에 알려진 가격 요인들로 설명이 되지 않는다. 개별종목의 횡단면 분석에서도 일간 승자/패자 종목들은 다른 개별종목 특성을 고려한 뒤에도 미래에 유의하게 낮은 수익을 낸다. 지난 한달 동안 일간 승자이면서 일간 패자였던 종목들의 경우, 기업 특성을 고려한 뒤에도 나머지 종목 들에 비해 월 평균 $2.64 \%$ 유의하게 낮은 수익을 얻었다.

둘째, 일간 승자/패자 종목을 제외한 대다수의 종목에서 고유변동성 이상현상이나 MAX 효과가 사라지거나 약해진다. 이는 미국시장을 대상으로 한 $\mathrm{KRU}$ 의 결과와 일관된 결과이다. 
Daily Winners and Losers in the Korean Stock Market

한국 주식시장에서도 고유변동성 이상현상이나 MAX 효과가 유의하게 발견되지만, 지난 한달 간 일간 승자였거나 패자였던 종목들을 제외한 뒤에는 고유변동성 이상현상과 MAX 효과가 유의하지 않은 수준으로 없어지거나, 그 정도가 약해지는 것을 볼 수 있다. 고유 변동성 이상현상이나 MAX 효과를 투자자들의 투기선호 현상으로 해석한다면, 일간 승자나 패자 종목들을 제외한 경우에도 고유변동성이나 MAX 정도에 따라 수익률이 달라져야 한다. 따라서 이 결과는 복권 성향 주식 선호보다는 일간 승자나 패자 종목들이 받게 되는 극단 적인 관심과 이로 인한 투자자들의 과도한 거래가 고유변동성 이상현상이나 MAX 효과의 근원이라는 점을 시사하고 있다.

셋째, 고유변동성 이상현상과 MAX 효과로 인한 수익률 차이는 일간 승자/패자 효과로 인한 수익률 차이로 설명할 수 있다. 고유변동성 이상현상이나 MAX 효과를 포착할 수 있는 매수-매도 포트폴리오 수익률을 일간 승자/패자 종목들을 매도하고 나머지 종목들을 매수하는 포트폴리오의 수익률이 설명한다. 반면에 일간 승자/패자 종목들을 매도하고 그 외의 종목들을 매수해서 얻을 수 있는 수익률을 MAX포트폴리오나 고유변동성 포트폴리오의 수익률이 설명하지는 못한다. 이는 위에서 고유변동성 이상현상과 MAX 효과의 주요 원인이 일간 승자/패자 효과라고 주장하는 것을 지지하는 증거이다.

마지막으로, 일간 승자/패자 종목을 주로 거래하는 투자자는 개인투자자이며, 일간 승자 /패자 종목의 수익률 차이가 큰 시기에 일간 승자/패자 종목의 미래수익률이 더 낮게 나타남을 확인할 수 있다. 투자자 그룹별 거래대금비중 변화를 살펴보면, 개인투자자들이 주로 눈에 띄는 종목들에 관심을 기울이며 많은 거래를 일으킨다. 이러한 개인투자자들의 과도한 관심이 개인 투자자들의 공매도 제한과 맞물려 과도한 가격 상승을 불러일으켰다고 추론할 수 있다. 반면에 기관투자자나 외국인 투자자는 눈에 띄는 일간 승자/패자 종목들에 대한 거래를 줄인 것을 확인 할 수 있다. 또한, 눈에 띄는 일간 상위/하위 종목들이 더욱 가시화되는 시기에 해당 종목들이 더욱 과대평가된다는 것을 보임으로써 관심으로 인한 과대평가와 이에 따른 낮은 수익이라는 일간 승자/패자 효과의 메커니즘을 다시 한번 확인 하는 결과를 얻었다.

국내에서 투자자의 관심과 주식수익률의 관계에 대해서 살펴본 연구에는 Lee et al. (2019), Kong and Park(2013) 등이 있다. Lee et al.(2019)는 한국 주식시장에서 투자자의 관심과 미래 수익률의 관계에 대해서 살펴본다. 개인투자자의 관심은 미래의 낮은 조정 수익률을 발생시키는 반면, 기관투자자와 외국인투자자의 관심은 지속적인 수익률 상승을 일으킨다는 것을 보인다. Kong and Park(2013)은 눈에 띄는 종목에 대한 개인투자자의 순매수거래량이 유의하게 증가하는 것을 보인다. 이 때, 거래량이 비정상적으로 증가한 종목과 극단적인 수익률을 갖는 종목들을 눈에 띄는 종목으로 분류한다. 이는 일간 승자/ 패자 종목에 대한 개인투자자들의 거래비중이 유의하게 증가하는 본 논문의 결과와도 일치하는 부분이다. 본 연구에서는 과도한 주의를 받게 되는 일간 승자/패자 종목들의 과대평가와 
한국증권학회지 제49권 4호 (2020)

낮은 미래수익이 기존에 알려진 고유변동성 이상현상이나 MAX 효과와 같은 이상현상들을 설명한다는 것을 보이는 데에 추가적인 공헌이 있다.

구성은 다음과 같다. 제 2장에서는 자료 및 일간 승자/패자의 특성에 대해 살펴보고, 제 3 장에서는 포트폴리오 분석 및 횡단면 분석으로 일간 승자/패자 효과의 존재 여부를 검정 하고 특징을 파악한다. 제 4장에서는 일간 승자/패자 효과와 고유변동성 이상현상, MAX 효과 사이의 관계에 대해서 분석한다. 제 5 장에서는 일간 승자/패자 종목을 주로 거래하는 투자자가 누구인지, 그리고 일간 승자/패자 효과의 시계열을 분석한다. 제 6장은 결론이다.

\section{2. 자료 및 일간 승자/패자(Daily Winners and Losers)}

본 연구의 표본은 2000년 1월부터 2017년 8월까지 한국거래소 유가증권시장(KOSPI)과 코스닥(KOSDAQ) 시장에 상장된 보통주이고, 에프앤가이드(FnGuide) 데이터베이스로부터 주식 수익률, 거래량, 재무정보를 수집하여 사용했다. 시장미시구조적 이유 등으로 월말 종가가 500원 이하인 주식은 해당 월 표본에서 제외한다. 그 결과 월 평균 약 1,611 개의 기업이 표본에 포함된다.

주요 분석은 1 개월간 일간 수익률이 상위권이나 하위권을 기록한 종목들의 미래 수익률을 살펴보는 것이다. 만약 $\mathrm{KRU}$ 의 분석대로 일간 수익률 상위권(일간 승자)이나 하위권(일간 패자)을 기록한 종목들이 많은 관심을 받아 과대평가 된다면, 미래수익률이 낮을 것이다. 일간 수익률이 상위권이나 하위권을 기록하지 않은 종목을 매수하고 일간 수익률이 상위권 이나 하위권을 기록한 종목들을 매도하는 전략을 취한다면 양의 수익을 거둘 것으로 기대 된다.

먼저, KRU의 일간 승자/패자 효과를 국내시장에서 검증해 보기 위해서, $\mathrm{KRU}$ 를 따라 일간 승자/패자 더미변수(dummy variable)들을 정의한다. $I_{W}$ 는 1 개월 동안 일간 수익률이 상위 $r$ 위 $(r=10,20,30)$ 이내인 날이 있다면 1 , 하루도 상위 $r$ 위 이내인 적이 없다면 0 인 더미변수이다. $I_{L}$ 은 1 개월 동안 일간수익률이 하위 $r$ 위 이내인 적이 하루라도 있다면 1 , 그렇지 않은 경우는 0 의 값을 갖는 더미변수이다. $I_{W L}$ 는 1 개월 동안 일간수익률이 상위 $r$ 위 이내인 날과 하위 $r$ 위 이내인 날이 동시에 존재하는 경우 1 , 그렇지 않은 경우 0 으로 정의한다. $\mathrm{KRU}$ 에서는 일간 상위/하위 종목을 선정하는 기준이 되는 순위를 80위 $(r=80)$ 로 선택한 반면, 본 연구에서는 국내 주식시장과 미국 주식시장에 상장된 종목 수와 변동성의 차이 등을 고려하여 10 위, 20 위, 30위 $(r=10,20,30)$ 를 선택하여 분석했다.

<표 1>의 패널 A는 매월 말, 일간 승자/패자 더미변수에 따라 포트폴리오를 구성했을 때, 각 포트폴리오에 속하는 주식의 비중을 보고한 것이다. 'BOTH'는 $I_{W L}$ 가 1 인 종목들로 구성한 포트폴리오이고, ‘WINNER'는 $I_{W}$ 가 1 인 종목들로 구성한 포트폴리오, 'LOSER'는 $I_{L}$ 이 1 인 종목들로 구성한 포트폴리오, 그리고 'NEVER'는 $I_{W}, I_{L}, I_{W L}$ 가 모두 0 인 종목들로 
Daily Winners and Losers in the Korean Stock Market

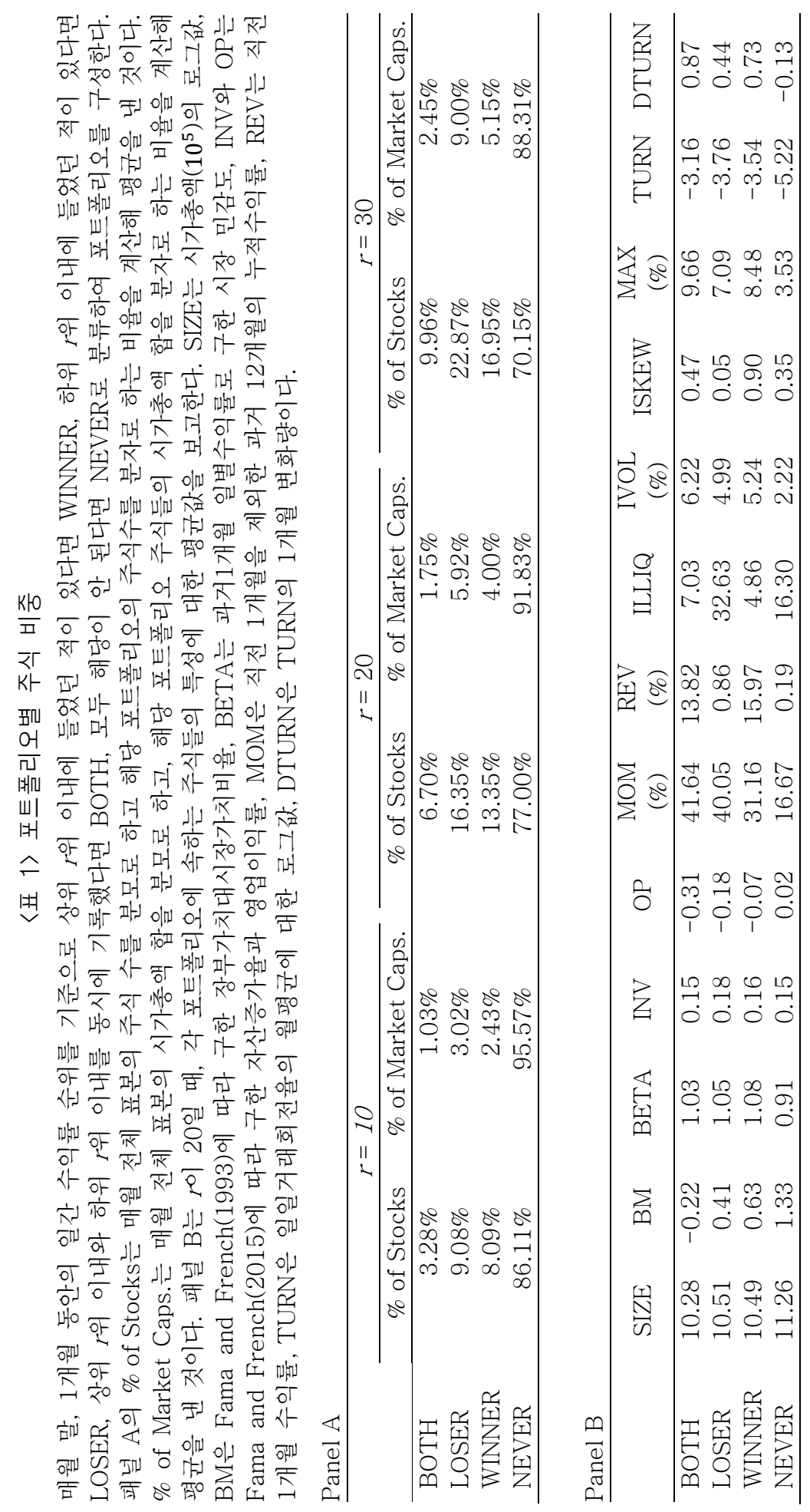


한국증권학회지 제49권 4호 (2020)

구성한 포트폴리오이다. 패널 A는 $r$ 이 $10,20,30$ 일 때 각 포트폴리오에 속하는 종목의 종목 수 비중과 가치 비중에 대한 통계량이다. 많은 관심을 받는 종목들을 고르려는 의도에 부합하는 모수 $r$ 을 선택하기 위해서, $\mathrm{KRU}$ 의 포트폴리오 별 주식 수 비중과 주식 가치 비중을 참고한다. KRU는 BOTH 포트폴리오에 속하는 주식 수(가치) 비중을 6.67\%(1.13\%)로 보고한다. 또한, NEVER 포트폴리오에 속하는 주식이 주식 수(가치) 기준 $77.88 \%(93.14 \%)$ 를 차지한다. 이와 비슷한 수준의 주식 수와 주식 가치 비중을 갖도록 하는 모수 $r$ 은 20이다. 우리는 앞으로 $r$ 이 20인 경우에 대해서 분석을 진행한다.

<표 1>의 패널 $\mathrm{B}$ 는 $r$ 이 20 인 경우, 각 포트폴리오에 속하는 종목의 월 평균 특성을 보여 준다. 기업규모(SIZE)와 장부가치대시장가치비율(BM)은 Fama and French(1993)에 따라 구한 시가총액의 로그값과 장부가치대시장가치비율, 시장베타(BETA)는 과거 1 개월의 일별 수익률로 구한 시장베타, 자산증가율(INV)과 영업이익(OP)은 Fama and French(2015)에 따라 구한 직전자산대비 자산 증가율과 자기자본 대비 영업이익률, 모멘텀(MOM)은 Jegadeesh and Titman(1993)에 입각하여 직전 1 개월을 제외한 과거 12 개월의 누적수익률이다. 단기 수익률반전(REV)은 직전 1 개월 수익률이고, 거래회전율(TURN)는 일일거래대금을 시가 총액으로 나눈 일일 거래회전율의 1 개월 평균에 대한 로그값, 거래회전율 변화(DTURN)는 거래회전율의 1 개월 변화량이다. 고유변동성(IVOL)은 Ang et al.(2006)에 따라 직전 1개월 각 주식의 일별수익률을 Fama and French(1993)의 3요인으로 조정한 잔차의 표준편차로 정의했고, 고유왜도(ISKEW)는 잔차의 왜도로 정의한다.

<표 1>의 패널 $\mathrm{B}$ 에서 $\mathrm{BOTH}$ 포트폴리오는 NEVER 포트폴리오에 비해 기업규모가 작고, 성장형(growth) 기업이고, 영업수익률이 크고, 최근 12 개월 수익률이 높은 기업이며, 고유 변동성이 크고, MAX가 큰 것을 확인할 수 있다. Kumar(2009)와 Bali et al.(2011)에서 복권 성향 주식은 소형주에 고유변동성과 MAX가 크다고 설명하는데, 이는 BOTH 포트 폴리오에 속하는 주식들의 특성과 일치한다. 주목할 만한 것은 거래회전율이다. 거래회전율을 비교해보면, BOTH 포트폴리오의 종목들은 NEVER 포트폴리오의 종목들에 비해서 현저히 거래가 많이 이루어지고, 거래량 증가가 큰 것으로 보아, 일간 승자/패자가 된 1 개월 동안 거래량이 많고, 거래량 유입이 많은 것을 확인할 수 있다. 일반적으로 투자자들의 관심과 거래량은 밀접한 관계가 있다고 알려져 있고, 투자자들의 관심을 측정하는 지표로 거래량 (volume)을 많이 사용한다. 일간 승자/패자 효과가 투자자들의 이목이 집중된 종목이어서 나타난다는 주장과 일관된 결과이다. LOSER 포트폴리오와 WINNER 포트폴리오 역시 기업 규모가 NEVER 포트폴리오의 주식들에 비해 작고, 장부가치대시장가치 비율이 작고, 영업 이익률이 낮은 경향이 있으며, 고유변동성이 크고, MAX가 크다. 거래회전율 역시 그 양과 증가량이 모두 NEVER 포트폴리오의 주식들보다 크게 나타난다. 일간 승자 종목과 일간 패자 종목 역시 투자자들에게 관심을 많이 받고, 따라서 많은 거래가 일어난다고 추론할 수 있다. 
Daily Winners and Losers in the Korean Stock Market

\section{3. 한국 주식 시장에서 일간 승자/패자 효과}

$\mathrm{KRU}$ 에 따르면, 미국 주식시장에서는 일간 승자/패자 종목의 경우, 다음달 초과수익률이 유의하게 낮아진다. 한국 시장에서도 이와 같은 일간 승자/패자 효과가 나타나는지 확인 하기 위해 일간 승자/패자 종목의 수익률을 살펴본다.

\section{1 포트폴리오 분석}

<표 2>의 패널 A는 $t$ 월에 일간 승자/패자 더미변수에 따라 구성한 가치가중(valueweighted) 포트폴리오와 동일가중(equal-weighted) 포트폴리오의 $t+1$ 월 수익률 횡단면을 나타낸 것이다. 미국 시장에서 나타났던 일간 승자/패자 효과와 마찬가지로 한국 주식시장 에서도 일간 승자/패자 종목은 미래에 낮은 수익률을 보인다. BOTH 포트폴리오의 월 평균 가치가중(동일가중) 수익률은 $-1.43 \%(-1.19 \%)$ 인 반면에, NEVER 포트폴리오의 월 평균 가치가중(동일가중) 수익률은 $0.86 \%(1.71 \%)$ 이다. WINNER 포트폴리오와 LOSER 포트 폴리오의 수익률은 BOTH 포트폴리오의 수익률보다는 높지만, NEVER 포트폴리오의 수익률보다는 낮은 것을 확인할 수 있다.

<표 2>의 패널 B에서는 NEVER 포트폴리오를 매수하고, BOTH 포트폴리오를 매도하는 전략(NMB), NEVER 포트폴리오를 매수하고 LOSER 포트폴리오를 매도하는 전략(NML)

〈표 2〉포트폴리오별 수익률

매월 말, 1 개월 동안의 일간 수익률 순위를 기준으로 상위 $\mathrm{r}$ 위 이내에 들었던 적이 있다면 WINNER, 하위 r위 이내에 들었던 적이 있다면 LOSER, 상위 r위 이내와 하위 $\mathrm{r}$ 위 이내를 동시에 기록했다면 $\mathrm{BOTH}$, 모두 해당이 안 된다면 NEVER로 분류하여 포트폴리오를 구성하고, 월별로 재조정한다. 패널 $\mathrm{A}$ 는 각 포트폴리오의 월평균 수익률과 $\mathrm{t}$ 값이다. $\mathrm{NMB}$ 는 NEVER 포트폴리오를 매수하고 BOTH 포트폴리오를 매도하는 전략의 수익률이고, NMW는 NEVER 포트폴리오를 매수, WINNER 포트폴리오를 매도하는 전략, NML은 NEVER 포트폴리오를 매수, LOSER 포트폴리오를 매도하는 전략의 수익률이다. FF3 alpha와 FF5 alpha는 각 포트폴리오 수익률을 Fama-French 3요인과 5 요인을 독립변수로 하는 시계열 회귀분석의 절편이다.

Panel A

\begin{tabular}{lrr}
\hline & 가치가중 & \multicolumn{1}{c}{ 동일가중 } \\
\hline BOTH & $-1.43(-1.60)$ & $-1.19(-1.75)$ \\
WINNER & $-0.63(-0.91)$ & $-0.34(-0.58)$ \\
LOSER & $-0.33(-0.46)$ & $-0.22(-0.32)$ \\
NEVER & $0.86(1.90)$ & $1.71(3.11)$ \\
\hline
\end{tabular}

Panel B

\begin{tabular}{llllllll}
\hline & \multicolumn{3}{c}{ 가치가중 } & & \multicolumn{3}{c}{ 동일가중 } \\
\cline { 2 - 3 } & 초과수익률 & FF3 alpha & FF5 alpha & & 초과수익률 & FF3 alpha & FF5 alpha \\
\hline NMB & $2.30(3.14)$ & $2.65(4.20)$ & $2.74(4.48)$ & & $2.91(7.04)$ & $2.81(6.95)$ & $2.34(5.84)$ \\
NMW & $1.49(3.07)$ & $1.93(4.44)$ & $1.72(3.87)$ & & $2.06(6.84)$ & $2.14(7.01)$ & $1.67(5.38)$ \\
NML & $1.19(2.41)$ & $1.41(3.09)$ & $1.44(3.26)$ & & $1.94(5.41)$ & $1.84(6.44)$ & $1.70(5.63)$ \\
\hline
\end{tabular}


한국증권학회지 제49권 4호 (2020)

그리고 NEVER 포트폴리오를 매수하고, WINNER 포트폴리오를 매도하는 전략(NMW)의 수익률을 보고한다. $\mathrm{NMB}$ 전략의 수익률은 월 평균 $2.30 \%$ 로 통계적으로 유의한 양의 값을 갖는다. Fama-French 3요인과 5요인으로 통제한 후에는 더 높은 $2.65 \%$ 와 $2.74 \%$ 이며 t 값도 더 높아지는 것을 확인할 수 있다. 즉, BOTH 포트폴리오가 NEVER 포트폴리오보다 수익률이 낮으며, 이 차이는 기존에 알려진 위험요인으로 설명되지 않는다. NMW 포트 폴리오의 수익률도 모두 양으로 유의한 값을 가진다. 지난달에 주목을 많이 받은 일간 승자들이 나머지 종목들에 비해서 낮은 수익을 낸다는 것을 확인할 수 있다. 놀라운 것은 NML 포트 폴리오의 수익도 아주 유의한 양의 값을 보인다는 것이다. 일간 패자들의 경우에도 다른 종목들에 비해서 낮은 수익을 낸다는 것이다. 일간 승자/패자 효과가 일간 승자 종목들에 국한된 현상이었다면, 이는 극단적으로 높은 수익률에 대한 반전효과로 해석할 수 있을 것이다. 하지만, 일간 패자 종목 역시 미래에 낮은 수익을 보이기 때문에 이는 승자와 패자 종목에 공통적으로 쏟아진 과도한 관심에서 기인한 현상으로 해석할 수 있다.

\section{2 개별종목 횡단면 분석}

이번에는 개별 종목 단위에서도 일간 승자/패자 효과가 나타나는지를 보기 위해 개별 주식들을 대상으로 Fama and MacBeth(1973)의 횡단면 회귀분석모형을 추정한다. 구체 적으로 다음의 식 (1)과 같이, 개별 주식의 초과수익률을 종속변수로, 주 더미변수들과 여러 기업특성을 설명변수로 한 횡단면 회귀분석의 회귀계수를 추정하고, 매월 추정한 각 회귀 계수의 시계열 평균을 <표 3 >에 보고한다.

$$
r_{i, t+1}=a_{0, t}+a_{1, t} I_{W L(i, t)}+a_{2, t} I_{W(i, t)}+a_{3, t} I_{L(i, t)}+a_{4, t}^{\prime} X_{i, t}+v_{i, t+1}
$$

$r_{i, t}$ 는 $t$ 월 주식 $i$ 의 초과수익률, $I_{W L(i, t)}$ 는 $t$ 월 주식 $i$ 의 $I_{W L}, I_{W(i, t)}$ 는 $t$ 월 주식 $i$ 의 $I_{W}, I_{L(i, t)}$ 는 $t$ 월 주식 $i$ 의 $I_{L}, X_{i, t}$ 는 $t$ 월 주식 $i$ 의 통제변수들로 시장민감도(BETA), 기업규모(SIZE), 장부가치대시장가치비율(BM), 과거누적수익률(MOM), 단기수익률반전(REV), 자산증가율(INV), 영업이익(OP), 거래회전율(TURN), 거래회전율변화(DTURN) 등을 포함한다.

<표 3> 첫 번째 열의 결과를 살펴보면, 직전 1 개월간 수익률 상위 20 위 이내와 하위 20 위 이내를 동시에 경험한 종목의 월 초과수익률이 그렇지 않은 종목들에 비해 평균 $2.64 \%$ 낮으며, 이 차이는 통계적으로 유의하다 $(\mathrm{t}=6.52) . \mathrm{KRU}$ 의 미국 주식시장 결과와 일관된 결과이다. 다른 독립변수들의 추정치를 보면, 한국 시장에서도 크기효과와 가치효과, 그리고 수익률 반전효과가 유의하게 나타남을 볼 수 있다. 하지만, 기존 문헌에서 밝혀진 바와 같이 한국 시장에서 유의한 모멘텀 효과는 나타나지 않는다. ${ }^{1)}$ 두 번째 열은 첫 번째

1) 외환위기 이후의 표본에서 국내 시장에도 모멘텀이 존재한다는 문헌들이 있다(Jang, 2017; Eom, 2013). 하지만, Jang(2017)의 표본은 유가증권시장만을 포함하고 있어 코스닥시장을 포함한 본 연구와는 표본이 다르다. 또한, $\operatorname{Eom}(2013)$ 에서는 국내 주식시장의 모멘텀이 시장구분, 평가기간, 
Daily Winners and Losers in the Korean Stock Market

열에 승자더미와 패자더미를 추가한 결과이다. 앞서 포트폴리오 분석에서 본 것과 마찬가지로, 일간 승자 종목들만 다음달 수익률이 낮은 것이 아니고, 일간 패자 종목 또한 다음달 수익률이 낮게 나타난다. 일간 패자 종목이었던 종목은 그렇지 않은 종목에 비해, 다른 특성을 조정하고서도, 평균적으로 월 $0.81 \%$ 낮은 수익을 낸다.

\section{〈표 3〉개별주식 횡단면 회귀분석}

식 (1)의 횡단면 회귀분석을 매월 추정하여 얻은 회귀계수의 평균 값과 그에 대한 t값이다. 각 종목의 월간 수익률에서 1 개월 통안채의 수익률을 제한 것을 종속변수로 한다. $I_{W}$ 은 1 개월간 일간수익률이 상위 20 위 이내였던 적이 있으면 1 인 더미변수, $I_{L}$ 은 1 개월간 일간수익률이 하위 20 위 이내였던 적이 있으면 1 인 더미변수, $I_{W L}$ 은 1 개월간 일간수익률이 상위 20 위 이내 하위 20 위 이내를 동시에 기록한 경우 1 인 더미변수이다. BETA는 과거1개월 일별수익률로 구한 시장민감도, SIZE는 시가 총액 $\left(10^{5}\right)$ 의 로그값, BM은 Fama and French(1993)에 따라 구한 장부가치대시장가치비율, INV와 OP는 Fama and French(2015)에 따라 구한 자산증가율과 영업이익율, MOM은 직전 1개월을 제외한 과거 12 개월의 누적수익률, REV는 직전 1 개월 수익률, TURN은 일일거래회전율의 월평균에 대한 로그값, DTURN은 TURN의 1개월 변화량이다.

\begin{tabular}{lcrrr}
\hline & $(1)$ & $(2)$ & \multicolumn{1}{c}{$(3)$} & \multicolumn{1}{c}{$(4)$} \\
\hline$I_{W L}$ & $-2.64(-6.52)$ & $-1.20(-3.94)$ & $-1.21(-4.01)$ & $-1.40(-4.71)$ \\
$I_{W}$ & & $-0.86(-4.03)$ & $-0.85(-4.04)$ & $-0.62(-2.62)$ \\
$I_{L}$ & & $-0.81(-3.08)$ & $-0.79(-3.08)$ & $-0.44(-1.67)$ \\
BETA & $0.11(0.84)$ & $0.12(0.90)$ & $0.13(1.05)$ & $0.22(2.12)$ \\
SIZE & $-0.55(-3.71)$ & $-0.58(-3.98)$ & $-0.56(-3.92)$ & $-0.64(-4.35)$ \\
BM & $0.34(2.94)$ & $0.31(2.81)$ & $0.30(2.81)$ & $0.24(2.37)$ \\
INV & & & $-0.57(-4.27)$ & \\
OP & & & $0.07(0.57)$ & \\
MOM & $-0.18(-0.84)$ & $-0.15(-0.73)$ & $-0.17(-0.84)$ & $-0.08(-0.37)$ \\
REV & $-4.32(-5.33)$ & $-3.98(-4.83)$ & $-3.94(-4.82)$ & $-3.70(-4.83)$ \\
TURN & & & & $-0.44(-3.64)$ \\
DTURN & & & & $0.10(0.93)$ \\
\hline
\end{tabular}

세 번째 열에서는 Fama and French(2015)를 따라 자산증가율(INV)과 영업이익(OP)을 추가로 통제했을 때의 결과를 보고한다. 기존 문헌의 결과들과 마찬가지로 투자가 많은 종목의 수익률이 유의하게 낮음을 보여주지만, 영업이익은 유의한 결과가 나타나지 않는다. 중요한 것은, 두 통제변수를 추가하고서도 주요 결과는 변하지 않는다는 것이다. 두 번째 열과 비교했을 때, 일간 승자/패자 더미들의 회귀계수 평균값은 크게 변하지 않았으며, $\mathrm{t}$ 값 역시 비슷한 수준이다. 추가된 기업특성 변수인 자산증가율과 영업이익이 일간 승자/패자 효과를 설명하지 못한다.

보유기간에 따라 다른 결과가 나타남을 보이며, 표본선정이 모멘텀 투자 전략에서 중요하다고 주장 한다. 유가증권시장과 코스닥 시장을 모두 포함한 Kang et al.(2013b)의 연구에서는 본 연구에서와 같이 모멘텀이 유의하지 않음을 보인다. 
한국증권학회지 제49권 4호 (2020)

일간 승자/패자 종목들은 투자자들의 이목을 끄는 종목들이라고 가정하고 있기 때문에, 기존에 투자자의 관심을 포착하는 변수로 쓰였던 거래회전율을 독립변수에 추가한 결과를 네 번째 열에 보고한다. 거래회전율을 통제한 후에도 일간 승자/패자 더미들이 모두 유의한 음의 추정값을 나타낸다. 본 연구에서는 일간 승자/패자 효과가 나타나는 원인을 투자자들의 많은 관심을 받은 종목들의 과대평가로 해석하고 있기 때문에, 이 결과는 주목할만하다. 일간 승자/패자에는 거래회전율이 담아내지 못한 추가적인 정보가 담겨있다고 해석할 수 있기 때문이다. 본 논문에서의 승자/패자는 극단적으로 관심을 끄는 종목들로 볼 수 있고 따라서 거래회전율이 포착하는 선형적 관심도를 뛰어넘는 관심도를 나타낸다. 이런 측면에서 보면, 거래회전율이 포착하는 투자자들의 관심 정도를 넘어서는 극단적인 관심 여부 또한 가격에 영향을 준다고 해석할 수 있다.

이상에서 우리는 포트폴리오 분석과 개별종목 횡단면 분석을 통해 일간 승자 종목이나 패자 종목의 미래 수익률이 낮은 현상을 확인했다. 즉, 일간 승자나 패자인 경우, 투자자 들을 많은 관심을 받게 되고, 따라서 과대평가된다는 주장을 지지하는 증거를 국내 시장 에서도 찾을 수 있었다.

\section{4. 고유변동성 이상현상, MAX효과와의 관계}

\section{1 고유변동성 이상현상, $\mathrm{MAX}$ 효과 재논의}

고유변동성 이상현상은 고유변동성이 높은 주식이 미래에 낮은 수익률을 갖는 현상이다. Ang et al.(2006)에서는 주식의 고유변동성과 주식수익률 간에 유의한 관계가 있음을 보인다. 또한 Bali et al.(2011)은 직전 1개월 동안의 일 최고수익률(MAX)이 높은 주식이 이후 수익률이 낮은 현상을 보고한다. 한국 주식시장에서의 고유변동성 이상현상과 MAX 효과는 Kim and Byun(2011), Kang and $\operatorname{Sim}$ (2014)에서 보고하고 있다.

선행연구에서는 이런 현상들을 설명하기 위해 투자자들의 선호에 대한 새로운 가설을 제시하고 있다. 투자자들이 복권 성향의 주식을 선호하고, 따라서 복권 성향의 주식들이 미래에 낮은 수익률을 보인다는 것이다. 고유변동성이 높거나 MAX가 높은 주식들 역시 복권처럼 희박한 가능성이지만 높은 이득을 얻을 가능성이 있는 자산이기 때문에 미래에 낮은 수익을 얻는다는 것이다. 또한, Kang and $\operatorname{Sim}(2014)$ 에서는 한국시장에서 MAX가 높은 주식들은 개인투자자의 거래비율이 높고, 또 개인투자자의 거래비율이 높은 주식에서 MAX효과가 더 유의하게 나타남을 보고한다. 개인투자자들의 복권 성향 주식선호가 이런 주식의 고평가로 이어지고, 결과적으로 미래에 수익이 낮아진다는 것이다.

하지만, $\mathrm{KRU}$ 에서는 고유변동성 이상현상과 MAX효과가 일간 승자/패자 주식들에서만 나타나고, 대부분의 주식에 해당하는 NEVER 포트폴리오에서는 나타나지 않음을 보이면서, 고유변동성 이상현상과 MAX 효과가 일간 승자/패자가 받는 투자자들의 많은 관심에 따른 과대평가 현상으로 설명이 된다고 보고한다. 
Daily Winners and Losers in the Korean Stock Market

본 연구는 한국 주식시장의 고유변동성 이상현상과 MAX효과도 일간 승자/패자 현상으로 설명할 수 있을지 확인해본다.

먼저, 고유변동성이 높은 주식의 낮은 미래수익률이 일간 승자/패자 효과에서 기인한 것인지를 확인하기 위해, 전체 주식포트폴리오에서의 고유변동성 이상현상과 일간 승자 /패자였던 적이 없는 NEVER 포트폴리오에서 고유변동성 이상현상을 살펴본다.

<표 4>의 패널 $\mathrm{A}$ 는 고유변동성을 기준으로 5 분위 포트폴리오를 구성하여 가치가중 포트 폴리오와 동일가중 포트폴리오의 월 평균수익률을 보고한다. 이 때, 첫 번째 행과 세 번째 행은 모든 주식을 대상으로 포트폴리오를 구성했을 때의 결과이고, 두 번째, 네 번째 행은 지난 1 개월간 일간 승자나 패자였던 적이 없는 NEVER 주식들을 대상으로 포트폴리오를 구성했을 때의 결과이다. 고유변동성 이상현상이 한국시장에도 존재함을 보였던 Kim and Byun(2011), Kang and $\operatorname{Sim}(2014)$ 의 결과와 마찬가지로 모든 주식을 대상으로 5분위 포트 폴리오를 구성한 경우에는 유의한 고유변동성 이상현상이 나타난다. 고유변동성이 가장 높은 포트폴리오의 월 평균 수익률과 고유변동성이 가장 낮은 포트폴리오의 월 평균 수익률 차이는 가치가중인 경우 $-1.30 \%$, 동일가중인 경우 $-1.51 \%$ 이고, 모두 통계적으로 유의하다.

〈표 4〉고유변동성 이상현상, MAX 효과와 일간 승자/패자의 관계

패널 $\mathrm{A}$ 는 고유변동성을 기준으로 5 분위로 나누어 월 평균 수익률과 $\mathrm{t}$ 값을 보고한다. 매달 일간 수익률을 Fama-French 3요인으로 조정하여 얻은 잔차의 표준편차를 고유변동성으로 정의한다. 패널 $\mathrm{B}$ 는 $\mathrm{MAX}$ 를 기준으로 5 분위로 나누어 월 평균 수익률과 $\mathrm{t}$ 값을 보고한다. 이 때, 직전 1 개월 동안 일간수익률의 최대값을 MAX로 정의한다. '모든 주식'은 본 연구 표본의 전체 주식을 대상으로 포트폴리오를 구성한 것이고, 'NEVER 주식'은 상위 20위 이내와 하위 20위 이내인 적이 없는 종목들로 포트폴리오를 구성한 것이다.

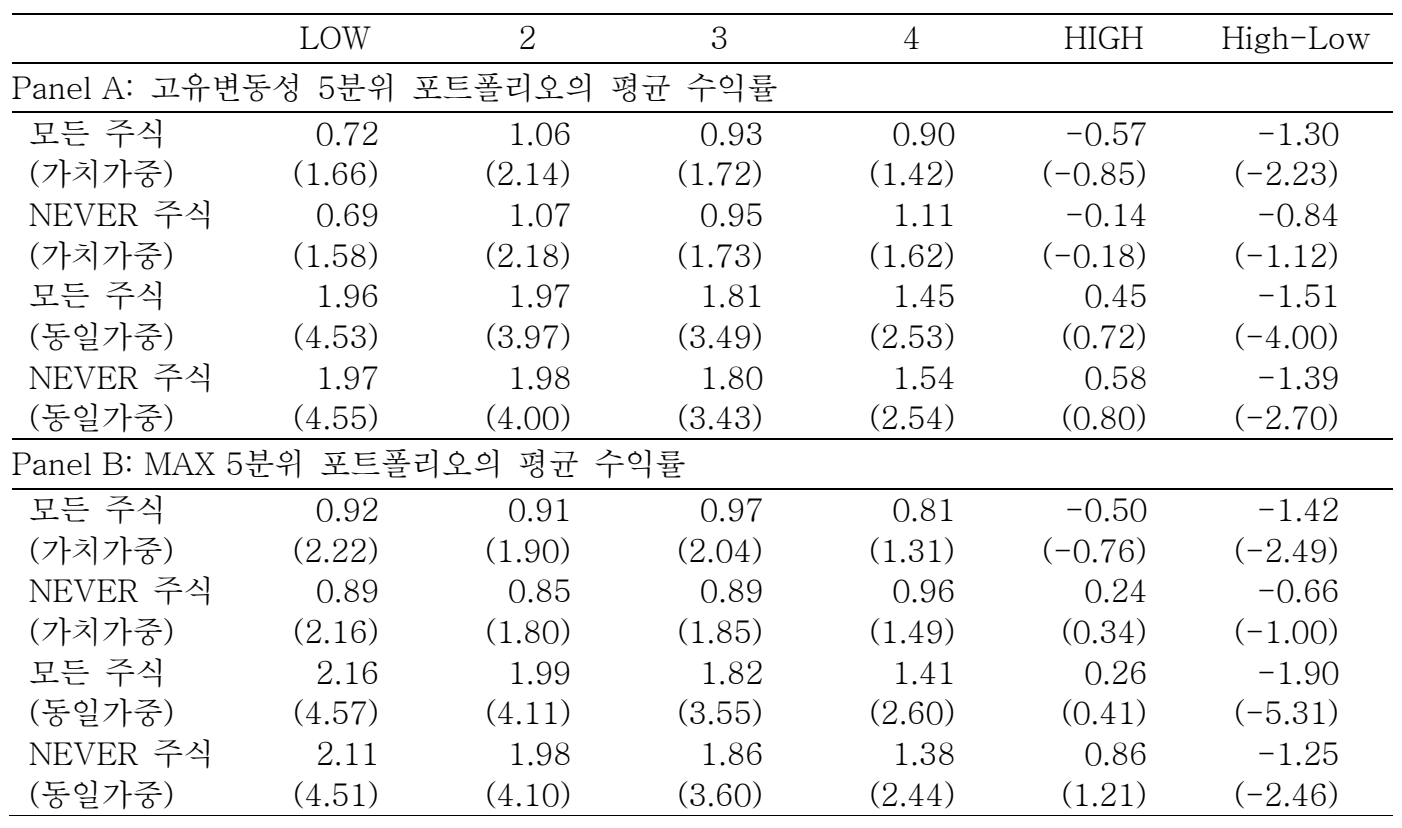


한국증권학회지 제49권 4호 (2020)

하지만, NEVER 주식을 대상으로 포트폴리오를 구성했을 때는 고유변동성 이상현상이 사라지거나 약해진다. 고유변동성이 가장 높은 포트폴리오와 가장 낮은 포트폴리오의 월 평균 수익률 차이는 가치가중의 경우 통계적으로 유의하지 않게 되고, 동일가중의 경우는 $-1.39 \%(\mathrm{t}=2.70)$ 으로 작아진다. NEVER 주식이 전체 주식에서 차지하는 비중이 주식 수 기준으로 약 $77 \%$, 가치 기준으로 약 $91.83 \%$ 임을 고려하면 대다수의 주식에서는 고유변동성 이상현상이 나타나지 않는 것이다.

<표 4>의 패널 B에서는 MAX 효과에 대해서 같은 방식으로 분석한 결과를 보고한다. MAX 효과 또한 전체 주식을 대상으로 한 포트폴리오에서는 유의하게 나타난다. MAX가 큰 주식과 MAX가 작은 주식의 수익률 차이는 월간 가치가중으로 $-1.42 \%(\mathrm{t}=2.49)$, 동일 가중으로 $-1.90 \%(\mathrm{t}=5.31)$ 로 그 차이가 크고 통계적으로 유의하다. 일간 승자나 패자였던 주식들을 제외한 NEVER 포트폴리오에서는 MAX 효과가 나타나지 않거나 약해지는 것을 확인할 수 있다.

정리해보면, 그동안 알려졌던 고유변동성 이상현상과 $\mathrm{MAX}$ 효과는 많은 주목을 받는 일부 일간 승자/패자 주식에만 국한된 현상이고, 그 외의 주식들에서는 나타나지 않는 현상 이라는 것이다. 이는 고유변동성 이상현상과 MAX 효과를 투자자들의 일간 승자/패자 효과로 설명할 수 있다는 가능성을 시사한다.

\subsection{NMB포트폴리오와 고유변동성 이상현상, MAX 효과}

다음은 NEVER 포트폴리오를 매수하고 BOTH 포트폴리오를 매도하는 전략(NMB)의 유의한 양의 수익률이 고유변동성 이상현상이나 MAX 효과로 설명되는지를 살펴본다. 이를 위해, Barillas and Shanken(2017)과 Fama and French(2018)의 방법론을 따라 스패닝 분석(spanning test)을 수행한다. 구체적으로, $\mathrm{NMB}$ 포트폴리오 수익률을 종속변수로, 고유 변동성이 큰 포트폴리오와 고유변동성이 작은 포트폴리오를 매수-매도하는 전략의 수익률, $\mathrm{MAX}$ 가 큰 포트폴리오와 MAX가 작은 포트폴리오를 매수-매도하는 전략의 수익률, 그리고 잘 알려진 가격 요인들(Fama-French 3요인, Fama-French 5요인)을 독립변수로 하는 시계열 회귀분석을 통해 확인한다.

<표 5>는 회귀분석 결과를 보고한다. 모델 1 부터 6 까지는 $\mathrm{NMB}$ 포트폴리오와 고유변동성 포트폴리오, MAX 포트폴리오를 가치가중으로 구성했을 때의 시계열 회귀분석 결과이고, 모델 7 부터 12 까지는 $\mathrm{NMB}$ 포트폴리오와 고유변동성 포트폴리오, MAX 포트폴리오를 동일 가중으로 구성했을 때의 결과이다. 모델 1 의 결과를 보면, 고유변동성 포트폴리오 수익률에 대한 $\mathrm{NMB}$ 포트폴리오 수익률의 민감도는 유의한 음의 값을 갖는다. 하지만 고유변동성 포트폴리오 수익률이 NMB포트폴리오의 유의한 양의 수익률을 모두 설명하지는 못한다. $\mathrm{NMB}$ 포트폴리오는 Fama-French 3요인과 고유변동성 포트폴리오 수익률을 모두 통제하고도 월 평균 2.07\%(t = 3.33)의 초과 수익을 낸다. 모델 2에서는 $\mathrm{NMB}$ 포트폴리오의 양의 수익률을 MAX 포트폴리오의 수익률이 모두 설명하지 못한다는 것을 보인다. MAX포트폴리오 수익률에 
Daily Winners and Losers in the Korean Stock Market

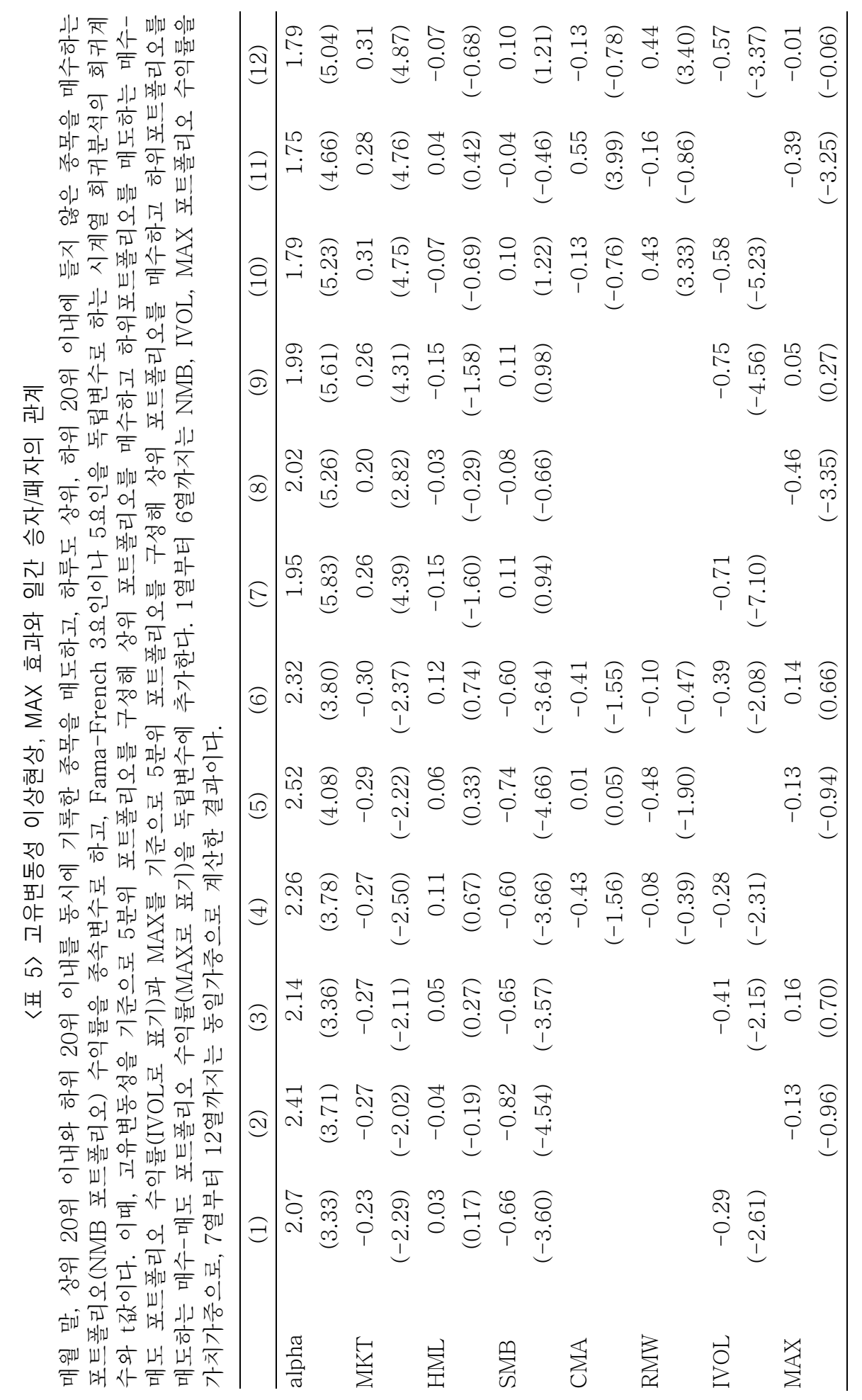


한국증권학회지 제49권 4호 (2020)

대한 민감도는 유의하지 않다. 고유변동성 포트폴리오 수익률과 MAX 포트폴리오 수익률을 동시에 통제한 결과에서도 $\mathrm{NMB}$ 포트폴리오의 수익은 양으로 유의하다. 모델 4, 5, 6에서는 추가적으로 Fama-French의 5요인을 통제했지만, 여전히 $\mathrm{NMB}$ 포트폴리오의 수익은 양으로 유의하다. Fama-French 3요인을 조정한 NMB 포트폴리오의 수익률이 월 평균 2.65\%(t $=4.20)$, Fama-French 5요인을 조정한 $\mathrm{NMB}$ 포트폴리오 수익률이 월 평균 2.74\%(t $=4.48)$ 임을 보고한 <표 2>의 결과와 비교했을 때, 고유변동성 포트폴리오 수익률이나 MAX 포트폴리오 수익률이 $\mathrm{NMB}$ 포트폴리오 수익률을 설명하는 데에 기여한 정도가 크지 않아 보인다. 모델 7 부터 12 까지의 결과는 모델 1 부터 6 까지의 결과와 질적으로 유사하다. $\mathrm{NMB}$ 포트폴리오 수익률은 가치가중으로 포트폴리오를 구성하든 동일가중으로 포트폴리오를 구성하든 고유 변동성 포트폴리오 수익률이나 MAX 포트폴리오 수익률이 완전히 설명하지 못한다.

<표 6>의 결과들을 바탕으로 고유변동성이 높은 포트폴리오를 매수하고, 고유변동성이 낮은 포트폴리오를 매도하는 고유변동성 포트폴리오의 수익률을 $\mathrm{NMB}$ 포트폴리오 수익률이 설명할 수 있을 것이라는 기대를 할 수 있다. 이를 확인해 보기 위해, 고유변동성 포트폴리오의 수익률을 종속변수로 하고, $\mathrm{NMB}$ 포트폴리오 수익률과 가격 요인들을 통제변수로 하는 회귀분석을 수행한다. 〈표 6>의 패널 $\mathrm{A}$ 는 그 결과를 나타낸다. 첫 번째 열에서는 고유변동성 효과가 알려진 가격요인으로 설명할 수 없다는 것을 보인다. 고유변동성이 높은 포트폴리오가 고유변동성이 낮은 포트폴리오보다 가격요인을 통제한 뒤에도 월 평균 $1.68 \%(\mathrm{t}=3.56)$ 낮다. 두 번째 열에서는 $\mathrm{NMB}$ 포트폴리오 수익률을 독립변수에 추가하자 절편이 0 에 가까워진다 $(\mathrm{t}$ = 1.99). 기대한 것과 마찬가지로, $\mathrm{NMB}$ 포트폴리오 수익률이 고유변동성에 의한 수익률 차이를 설명한다. 동일가중으로 구성한 고유변동성 포트폴리오의 수익률의 경우에도, $\mathrm{NMB}$ 를 통제하기 전에는 유의한 음의 수익률을 갖지만 $(-0.94 \%, \mathrm{t}=2.98), \mathrm{NMB}$ 를 통제한 뒤에는 t값이 0.08 이 된다.

마찬가지 방법으로 $\mathrm{MAX}$ 포트폴리오 수익률 또한 $\mathrm{NMB}$ 포트폴리오 수익률이 설명하는 지를 확인한다. 〈표 6>의 패널 $\mathrm{B}$ 에서 그 결과를 보인다. MAX가 큰 포트폴리오의 수익률이 $\mathrm{MAX}$ 가 작은 포트폴리오 수익률보다 가치가중(동일가중)인 경우 월 평균 $1.67 \%(1.52 \%)$ 작다. MAX 효과가 알려진 가격요인들로는 설명이 되지 않는 것이다. 이 때, $\mathrm{NMB}$ 포트폴리오 수익률을 독립변수로 추가하면, 절편이 가치가중(동일가중)인 경우 $-1.08 \%(-0.73 \%)$ 로 작아 지며, t값은 2.08(2.00)이 된다. NMB 포트폴리오 수익률이 MAX 포트폴리오 음의 수익률을 많은 부분 설명하는 것으로 보인다.

지금까지의 결과들은 다음과 같은 내용을 시사한다. 첫째, 고유변동성 이상현상과 MAX 효과는 일부의 많은 관심을 받은 주식들의 고평가에서 기인한다. 이는 고유변동성 이상현상 이나 MAX 효과와 같은 이상현상들에 대한 주요 원인을 주식투자자들의 복권 성향 주식 선호로 설명했던 기존의 결과들과는 차이가 있다. 둘째, 고유변동성이 낮은 주식과 높은 주식의 수익률 차이는 관심을 특별히 많이 받은 일간 승자/패자 주식과 나머지 주식의 수익률 차이로 대부분 설명할 수 있다. MAX가 큰 주식과 작은 주식의 수익률 차이 역시 일간 승자 
Daily Winners and Losers in the Korean Stock Market

/패자 주식과 나머지 주식의 수익률 차이로 설명할 수 있다. 이는 극단적인 관심을 포착 하는 일간 승자/패자 정보가 고유변동성과 MAX의 정보를 포괄하며, 따라서 고유변동성 이상현상과 MAX 효과가 일간 승자/패자 효과를 근원으로 하고 있다고 해석할 수 있다.

〈표 6〉 고유변동성 이상현상, MAX 효과와 일간 승자/패자의 관계

패널 A는 고유변동성 포트폴리오 수익률(IVOL로 표기)을 종속변수로 하고, NMB 포트폴리오 수익률과 Fama-French 3요인이나 5요인을 독립변수로 하는 시계열 회귀분석의 회귀계수와 t값 이다. 이 때, 고유변동성 포트폴리오는 고유변동성을 기준으로 5 분위 포트폴리오를 구성해 상위 포트폴리오를 매수하고 하위포트폴리오를 매도하는 매수-매도 포트폴리오 이고, NMB 포트폴리오는 상위 20 위 이내와 하위 20 위 이내를 동시에 기록한 종목을 매도하고, 하루도 상위, 하위 20 위 이내에 들지 않은 종목을 매수하는 포트폴리오이다. 패널 $\mathrm{B}$ 는 $\mathrm{MAX}$ 포트폴리오 수익률(MAX로 표기)을 종속변수로 하고, NMB 포트폴리오 수익률과 Fama-French 3요인이나 5요인을 독립변수로 하는 시계열 회귀분석의 회귀계수와 t값이다. 이 때, MAX 포트폴리오는 MAX를 기준으로 5 분위 포트 폴리오를 구성해 상위 포트폴리오를 매수하고 하위포트폴리오를 매도하는 매수-매도 포트폴리오 이다. 각 패널의 1 열과 2 열은 IVOL, MAX, $\mathrm{NMB}$ 포트폴리오를 가치가중으로 구성하고, 3 열과 4 열은 동일가중으로 구성한다.

Panel A

\begin{tabular}{lrrrr}
\hline & \multicolumn{1}{c}{ IVOL_VW } & \multicolumn{1}{c}{ IVOL_VW } & \multicolumn{1}{c}{ IVOL_EW } & \multicolumn{1}{c}{ IVOL_EW } \\
\hline alpha & $-1.68(-3.56)$ & $-0.96(-1.99)$ & $-0.94(-2.98)$ & $-0.02(-0.08)$ \\
MKT & $0.30(2.77)$ & $0.19(1.59)$ & $0.15(2.59)$ & $0.23(4.58)$ \\
HML & $0.24(1.70)$ & $0.26(1.85)$ & $-0.34(-3.78)$ & $-0.29(-3.48)$ \\
SMB & $0.74(6.04)$ & $0.46(3.34)$ & $0.49(6.26)$ & $0.34(4.36)$ \\
CMA & $0.16(0.51)$ & $0.24(0.91)$ & $0.00(0.01)$ & $-0.03(-0.29)$ \\
RMW & $-0.42(-2.40)$ & $-0.63(-3.68)$ & $-0.34(-2.81)$ & $-0.18(-1.78)$ \\
NMB & & $-0.18(-3.46)$ & & $-0.37(-7.24)$ \\
\hline
\end{tabular}

Panel B

\begin{tabular}{lrrrr}
\hline & \multicolumn{1}{c}{ MAX_VW } & \multicolumn{1}{c}{ MAX_VW } & \multicolumn{1}{c}{ MAX_EW } & \multicolumn{1}{c}{ MAX_EW } \\
\hline alpha & $-1.67(-3.86)$ & $-1.08(-2.08)$ & $-1.52(-4.00)$ & $-0.73(-2.00)$ \\
MKT & $0.46(4.58)$ & $0.37(3.50)$ & $0.16(2.12)$ & $0.20(2.79)$ \\
HML & $0.11(0.78)$ & $0.13(0.84)$ & $-0.24(-2.04)$ & $-0.15(-1.37)$ \\
SMB & $0.55(4.28)$ & $0.22(1.38)$ & $0.37(5.20)$ & $0.31(3.06)$ \\
CMA & $-0.03(-0.11)$ & $0.03(0.12)$ & $-0.05(-0.35)$ & $0.07(0.62)$ \\
RMW & $-0.21(-1.06)$ & $-0.48(-2.46)$ & $-0.21(-1.88)$ & $-0.03(-0.21)$ \\
NMB & & $-0.11(-1.22)$ & & $-0.31(-5.46)$ \\
\hline
\end{tabular}

\section{3 개별 종목 횡단면 분석}

개별 종목에서도 고유변동성 이상현상이나 MAX 효과가 일간 승자/패자 효과와 어떤 관계를 갖는지 살펴보기 위해서 Fama-MacBeth 횡단면 회귀분석을 추정한다. 식 (1)의 모형을 확장하여 고유변동성과 MAX를 독립변수에 추가한 식 (2)를 추정한다.

$$
r_{i, t+1}=a_{0, t}+a_{1, t} I_{W L(i, t)}+a_{2, t} I_{W(i, t)}+a_{3, t} I_{L(i, t)}+a_{4, t}{ }^{\prime} X_{i, t}+a_{5, t} I V O L_{i, t}+a_{6, t} M A X_{i, t}+v_{i, t+1}
$$


한국증권학회지 제49권 4호 (2020)

<표 7>에서는 식 (2)를 매 월 추정해 얻은 회귀계수의 평균을 보고한다. 모델 (1)에서 $I_{W L}$ 의 회귀계수는 유의한 음의 값을 갖는다. 이는 고유변동성의 차이에서 발생하는 자산 가격 차이로 설명할 수 없는 일간 승자/패자와 나머지 주식들 간의 유의한 수익률 차이가 있음을 의미한다. 모델 (2)에서는 일간 승자더미와 패자더미를 추가한 결과를 보고한다. $I_{W L}$ 의 회귀계수는 여전히 유의한 음의 값을 갖지만, $I_{W}$ 와 $I_{L}$ 의 회귀계수는 평균적으로 0 과 다르지 않다. <표 3>에서는 모든 승자/패자 더미변수들이 유의한 음의 회귀 계수를 나타낸 것과는 대조적이다. 모델 (3)은 통제변수에 MAX를 추가한 결과이다. 고유변동성과 마찬가지로 MAX의 차이에서 발생하는 수익률 차이가 일간 승자/패자 효과를 모두 설명하지 못한다. 일간 승자더미와 패자더미를 추가한 모델 (4)의 결과는 모델 (2)와 마찬가지로 일간 승자

\section{〈표 7〉개별주식 횡단면 회귀분석-고유변동성, MAX}

횡단면 회귀분석을 매월 추정하여 얻은 회귀계수의 평균 값과 그에 대한 $\mathrm{t}$ 값이다. 각 종목의 월간 수익률에서 1 개월 통안채의 수익률을 제한 것을 종속변수로 한다. $I_{W}$ 은 1 개월간 일간수익률이 상위 20 위 이내였던 적이 있으면 1 인 더미변수, $I_{L}$ 은 1 개월간 일간수익률이 하위 20 위 이내였던 적이 있으면 1 인 더미변수, $I_{W L}$ 은 1 개월간 일간수익률이 상위 20 위 이내 하위 20 위 이내를 동시에 기록한 경우 1 인 더미변수이다. BETA는 과거1개월 일별수익률로 구한 시장 민감도, SIZE는 시가 총액 $\left(10^{5}\right)$ 의 로그값, BM은 Fama and French(1993)에 따라 구한 장부가치대시장가치비율, INV와 $\mathrm{OP}$ 는 Fama and French(2015)에 따라 구한 직전자산대비 자산증가율과 자기자본대비 영업이익율, MOM은 Jagadeesh and Titman(1993)을 따라 직전 1개월을 제외한 과거 12개월의 누적수익률, $\mathrm{REV}$ 는 직전 1 개월 수익률, IVOL은 일간수익률을 $\mathrm{FF}$ 3요인으로 조정하여 얻은 잔차의 표준편차, $\mathrm{MAX}$ 는 일간수익률의 최대값이다.

\begin{tabular}{lrrrrrr}
\hline & \multicolumn{1}{c}{$(1)$} & \multicolumn{1}{c}{$(2)$} & \multicolumn{1}{c}{$(3)$} & \multicolumn{1}{c}{$(4)$} & \multicolumn{1}{c}{$(6)$} \\
\hline$I_{W L}$ & -1.08 & -1.21 & -1.07 & -1.06 & -0.95 & -1.06 \\
$I_{W}$ & $(-2.99)$ & $(-4.01)$ & $(-2.87)$ & $(-3.66)$ & $(-2.65)$ & $(-3.61)$ \\
& & 0.20 & & -0.05 & & 0.14 \\
$I_{L}$ & & $(0.87)$ & & $(-0.21)$ & & $(0.61)$ \\
\multirow{2}{*}{ BETA } & & 0.04 & & 0.04 & & 0.06 \\
& & $(0.15)$ & & $(0.14)$ & & $(0.20)$ \\
SIZE & 0.19 & 0.19 & 0.36 & 0.36 & 0.38 & 0.37 \\
& $(1.44)$ & $(1.45)$ & $(2.01)$ & $(1.96)$ & $(1.72)$ & $(1.72)$ \\
BM & -0.65 & -0.64 & -0.62 & -0.62 & -0.64 & -0.64 \\
& $(-4.48)$ & $(-4.51)$ & $(-4.20)$ & $(-4.23)$ & $(-4.48)$ & $(-4.51)$ \\
MOM & 0.24 & 0.23 & 0.23 & 0.23 & 0.23 & 0.22 \\
& $(2.26)$ & $(2.22)$ & $(2.20)$ & $(2.19)$ & $(2.18)$ & $(2.14)$ \\
REV & -0.11 & -0.11 & -0.11 & -0.10 & -0.08 & -0.08 \\
& $(-0.51)$ & $(-0.52)$ & $(-0.50)$ & $(-0.48)$ & $(-0.38)$ & $(-0.40)$ \\
IVOL & -3.16 & -2.97 & -1.58 & -1.49 & -1.89 & -1.85 \\
& $(-3.87)$ & $(-3.58)$ & $(-1.69)$ & $(-1.54)$ & $(-1.89)$ & $(-1.88)$ \\
MAX & -50.33 & -53.60 & & & -25.89 & -30.84 \\
& $(-5.43)$ & $(-4.92)$ & & & $(-1.78)$ & $(-2.06)$ \\
& & & -36.81 & -37.04 & -21.47 & -19.88 \\
& & & $(-5.44)$ & $(-4.88)$ & $(-1.94)$ & $(-1.78)$ \\
\hline
\end{tabular}


Daily Winners and Losers in the Korean Stock Market

이기만 하거나 일간 패자이기만 한 종목의 과대평가는 MAX 효과로 설명되는 것을 볼 수 있다. 모델 (5)와 모델 (6)에서는 고유변동성과 MAX를 동시에 통제한 결과이다. 두 경우 모두 $I_{W L}$ 의 회귀계수는 유의한 음의 값을 갖는다.

정리하자면, 일간 승자/패자 종목의 낮은 미래 수익률은 높은 고유변동성에서 기인한 낮은 수익이나 높은 MAX로 인한 낮은 수익만으로는 설명이 안 된다. 이는 일간 승자/패자 종목에 몰리는 투자자들의 높고 극단적인 관심은 기존의 개인투자자들의 복권 성향 주식 특징만으로는 포착할 수 없는 추가적인 현상으로 이해할 수 있다.

\section{5. 투자자별 거래 행태 및 시계열 분석}

\section{1 일간 승자/패자 종목의 투자자 별 거래 비율}

그렇다면, 눈에 띄는 일간 승자/패자 종목들을 주로 거래한 투자자 그룹은 어떤 그룹일까? $\mathrm{KRU}$ 에서는 개인투자자들과 기관투자자들의 매수-매도 불균형(buy-sell imbalance) 정보를 이용하여 일간 승자나 패자 종목들에 대해 개인투자자들이 매수를 늘리는 경향이 있고, 기관투자자들이 매도를 늘리는 경향이 있음을 보였다. 우리는 자료의 제약으로 매수-매도 불균형 정보를 이용하는 데에는 한계가 있어, 이를 대체하기 위해 투자자 주체 별 거래대금 비중을 이용하여 분석한다.

일간 승자/패자 종목들에 대해서 해당 월에 개인투자자, 기관투자자, 외국인투자자가 거래대금 비중을 지난달에 비해서 늘렸는지 줄였는지에 대해서 횡단면 회귀분석을 한다. 다음의 식 (4)를 매월 추정하여 Fama-MacBeth의 방식을 따라 회귀계수의 시계열 평균을 <표 8>에 보고한다.

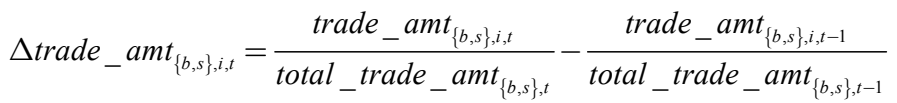

$$
\begin{aligned}
& \Delta \text { trade_amt } t_{\{b, s\}, i, t}=a_{0, t}+a_{1, t} I_{W L(i, t)}+a_{2, t} I_{W(i, t)}+a_{3, t} I_{L(i, t)}+a_{4, \mathrm{t}}{ }^{\prime} X_{i, t}+v_{i, t+1}
\end{aligned}
$$

이 때, trade_amt $t_{\{b, s\}, i, t}$ 는 $t$ 월 $i(i=$ 개인투자자, 기관투자자, 외국인투자자)의 매수(b)/매도(s) 거래대금, total_trade_amt $t_{\{b, s\}, t}$ 는 $t$ 월 총 매수(b)/매도(s) 거래대금이다. <표 8>의 패널 $\mathrm{A}$ 는 개인투자자의 거래대금비중 변동에 대한 결과이다. 기대와 마찬가지로, 개인투자자들은 일간 승자/패자 종목들에 대한 거래를 늘리는 경향이 있다. 첫 번째, 세 번째, 다섯 번째 열은 매도거래대금 비중에 대한 결과이고, 두 번째, 네 번째, 여섯 번째 열은 매수거래대금 비중에 대한 결과이다. 개인투자자들은 일간 승자/패자를 모두 경험한 종목들에 대한 매수 거래비중을 나머지 종목에 비해 $1.64 \%(\mathrm{t}=7.97)$ 더 늘렸다. 또한 일간 승자 종목과 일간 패자 종목에 대한 매수거래비중 증가가 나머지 종목에 비해 $1.44 \%(\mathrm{t}=3.60), 1.91 \%(\mathrm{t}=6.64)$ 많은 것을 확인할 수 있다. 일간 승자/패자 종목에 대한 매도거래비중 증가는 나머지 종목 


\section{〈표 8〉투자자 별 일간 승자/패자 종목 거래비율 변동}

식 (8)의 횡단면 회귀분석을 매월 추정하여 얻은 회귀계수의 평균 값과 그에 대한 t값이다. 개인투자자, 기관투자자, 외국인투자자의 각 월간거래대금을 총 거래대금으로 나눈 것의 1 차분을 각각 패널 $\mathrm{A}$, 패널 $\mathrm{B}$, 패널 $\mathrm{C}$ 의 종속변수로 한다. $I_{W}$ 은 1 개월간 일간수익률이 상위 20 위 이내였던 적이 있으면 1 인 더미변수, $I_{L}$ 은 1 개월간 일간수익률이 하위 20 위 이내였던 적이 있으면 1 인 더미변수, $I_{W L}$ 은 1 개월간 일간수익률이 상위 20 위 이내 하위 20 위 이내를 동시에 기록한 경우 1 인 더미변수이다. BETA는 과거 1 개월 일별수익률로 구한 시장 민감도, SIZE는 시가총액 $\left(10^{5}\right)$ 의 로그값, BM은 Fama and French(1993)에 따라 구한 장부가치대시장가치비율, INV와 OP는 Fama and French(2015)에 따라 구한 직전자산대비 자산증가율과 자기자본대비 영업이익률, MOM은 Jagadeesh and Titman(1993)을 따라 직전 1 개월을 제외한 과거 12 개월의 누적수익률, REV는 직전 1 개월 수익률이다.

Panel A: 개인투자자의 거래대금비중 증감

\begin{tabular}{|c|c|c|c|c|c|c|}
\hline \multirow{2}{*}{$I_{W L}$} & 매도 & 매수 & 매도 & 매수 & 매도 & 매수 \\
\hline & $\begin{array}{r}0.34 \\
(1.71)\end{array}$ & $\begin{array}{r}1.64 \\
(7.97)\end{array}$ & & & & \\
\hline$I_{W}$ & & & $\begin{array}{r}0.66 \\
(1.78)\end{array}$ & $\begin{array}{r}1.44 \\
(3.60)\end{array}$ & & \\
\hline$I_{L}$ & & & & & $\begin{array}{r}0.33 \\
(1.83)\end{array}$ & $\begin{array}{r}1.91 \\
(6.64)\end{array}$ \\
\hline BETA & $\begin{array}{r}-0.03 \\
(-0.13)\end{array}$ & $\begin{array}{r}-0.17 \\
(-0.81)\end{array}$ & $\begin{array}{r}-0.02 \\
(-0.09)\end{array}$ & $\begin{array}{r}-0.16 \\
(-0.78)\end{array}$ & $\begin{array}{r}-0.03 \\
(-0.13)\end{array}$ & $\begin{array}{r}-0.19 \\
(-1.00)\end{array}$ \\
\hline SIZE & $\begin{array}{r}-0.01 \\
(-0.12)\end{array}$ & $\begin{array}{r}0.02 \\
(0.45)\end{array}$ & $\begin{array}{r}0.01 \\
(0.17)\end{array}$ & $\begin{array}{r}0.04 \\
(0.72)\end{array}$ & $\begin{array}{r}0.01 \\
(0.12)\end{array}$ & $\begin{array}{r}0.07 \\
(1.33)\end{array}$ \\
\hline $\mathrm{BM}$ & $\begin{array}{r}0.01 \\
(0.22)\end{array}$ & $\begin{array}{r}0.04 \\
(1.32)\end{array}$ & $\begin{array}{r}0.01 \\
(0.50)\end{array}$ & $\begin{array}{r}0.05 \\
(1.59)\end{array}$ & $\begin{array}{r}0.01 \\
(0.46)\end{array}$ & $\begin{array}{r}0.07 \\
(2.11)\end{array}$ \\
\hline MOM & $\begin{array}{r}-0.55 \\
(-9.77)\end{array}$ & $\begin{array}{r}-0.02 \\
(-0.47)\end{array}$ & $\begin{array}{r}-0.56 \\
(-9.67)\end{array}$ & $\begin{array}{r}-0.04 \\
(-0.65)\end{array}$ & $\begin{array}{r}-0.56 \\
(-9.71)\end{array}$ & $\begin{array}{r}-0.04 \\
(-0.69)\end{array}$ \\
\hline REV & $\begin{array}{r}6.51 \\
(5.74) \\
\end{array}$ & $\begin{array}{r}-3.76 \\
(-3.82) \\
\end{array}$ & $\begin{array}{r}6.58 \\
(5.84) \\
\end{array}$ & $\begin{array}{r}-3.28 \\
(-3.36) \\
\end{array}$ & $\begin{array}{r}6.22 \\
(5.68) \\
\end{array}$ & $\begin{array}{r}-4.83 \\
(-4.86) \\
\end{array}$ \\
\hline anel B: & E자자의 & 대금비중 & & & & \\
\hline & 매도 & 매수 & 매도 & 매수 & 매도 & 매수 \\
\hline$I_{W L}$ & $\begin{array}{r}0.02 \\
(0.41)\end{array}$ & $\begin{array}{r}-0.67 \\
(-13.29)\end{array}$ & & & & \\
\hline$I_{W}$ & & & $\begin{array}{r}-0.03 \\
(-0.64)\end{array}$ & $\begin{array}{r}-0.43 \\
(-9.00)\end{array}$ & & \\
\hline$I_{L}$ & & & & & $\begin{array}{r}-0.04 \\
(-0.57)\end{array}$ & $\begin{array}{r}-0.89 \\
(-15.47)\end{array}$ \\
\hline BETA & $\begin{array}{r}-0.11 \\
(-3.98)\end{array}$ & $\begin{array}{r}-0.05 \\
(-1.60)\end{array}$ & $\begin{array}{r}-0.11 \\
(-4.00)\end{array}$ & $\begin{array}{r}-0.05 \\
(-1.69)\end{array}$ & $\begin{array}{r}-0.11 \\
(-3.95)\end{array}$ & $\begin{array}{r}-0.02 \\
(-0.87)\end{array}$ \\
\hline SIZE & $\begin{array}{r}0.01 \\
(0.44)\end{array}$ & $\begin{array}{r}-0.01 \\
(-0.42)\end{array}$ & $\begin{array}{r}0.00 \\
(0.27)\end{array}$ & $\begin{array}{r}-0.01 \\
(-0.58)\end{array}$ & $\begin{array}{r}0.01 \\
(0.35)\end{array}$ & $\begin{array}{r}-0.03 \\
(-1.40)\end{array}$ \\
\hline $\mathrm{BM}$ & $\begin{array}{r}0.01 \\
(0.43)\end{array}$ & $\begin{array}{r}-0.01 \\
(-0.50)\end{array}$ & $\begin{array}{r}0.00 \\
(0.23)\end{array}$ & $\begin{array}{r}-0.01 \\
(-0.77)\end{array}$ & $\begin{array}{r}0.01 \\
(0.53)\end{array}$ & $\begin{array}{r}-0.02 \\
(-1.21)\end{array}$ \\
\hline MOM & $\begin{array}{r}0.29 \\
(9.46)\end{array}$ & $\begin{array}{r}-0.04 \\
(-1.60)\end{array}$ & $\begin{array}{r}0.29 \\
(9.50)\end{array}$ & $\begin{array}{r}-0.03 \\
(-1.34)\end{array}$ & $\begin{array}{r}0.29 \\
(9.50)\end{array}$ & $\begin{array}{r}-0.03 \\
(-1.40)\end{array}$ \\
\hline REV & $\begin{array}{r}-2.92 \\
(-9.98)\end{array}$ & $\begin{array}{r}3.33 \\
(11.15)\end{array}$ & $\begin{array}{r}-2.89 \\
(-10.17)\end{array}$ & $\begin{array}{r}3.14 \\
(10.74)\end{array}$ & $\begin{array}{r}-2.90 \\
(-9.39)\end{array}$ & $\begin{array}{r}3.79 \\
(11.56)\end{array}$ \\
\hline
\end{tabular}


Daily Winners and Losers in the Korean Stock Market

〈표 8〉 투자자 별 일간 승자/패자 종목 거래비율 변동(계속)

Panel C: 외국인투자자의 거래대금비중 증감

\begin{tabular}{|c|c|c|c|c|c|c|}
\hline & 매도 & 매수 & 매도 & 매수 & 매도 & 매수 \\
\hline$I_{W L}$ & $\begin{array}{r}-0.26 \\
(-3.74)\end{array}$ & $\begin{array}{r}-0.57 \\
(-6.76)\end{array}$ & & & & \\
\hline$I_{W}$ & & & $\begin{array}{r}-0.24 \\
(-4.17)\end{array}$ & $\begin{array}{r}-0.34 \\
(-6.12)\end{array}$ & & \\
\hline$I_{L}$ & & & & & $\begin{array}{r}-0.27 \\
(-3.22)\end{array}$ & $\begin{array}{r}-0.69 \\
(-6.30)\end{array}$ \\
\hline BETA & $\begin{array}{r}-0.03 \\
(-1.46)\end{array}$ & $\begin{array}{r}0.01 \\
(0.38)\end{array}$ & $\begin{array}{r}-0.03 \\
(-1.40)\end{array}$ & $\begin{array}{r}0.01 \\
(0.36)\end{array}$ & $\begin{array}{r}-0.02 \\
(-1.15)\end{array}$ & $\begin{array}{r}0.02 \\
(0.59)\end{array}$ \\
\hline SIZE & $\begin{array}{r}0.01 \\
(0.46)\end{array}$ & $\begin{array}{r}0.01 \\
(0.21)\end{array}$ & $\begin{array}{r}0.01 \\
(0.39)\end{array}$ & $\begin{array}{r}0.01 \\
(0.23)\end{array}$ & $\begin{array}{r}0.01 \\
(0.28)\end{array}$ & $\begin{array}{r}-0.01 \\
(-0.16)\end{array}$ \\
\hline $\mathrm{BM}$ & $\begin{array}{r}0.00 \\
(0.11)\end{array}$ & $\begin{array}{r}-0.01 \\
(-0.91)\end{array}$ & $\begin{array}{r}0.00 \\
(-0.54)\end{array}$ & $\begin{array}{r}-0.01 \\
(-1.11)\end{array}$ & $\begin{array}{r}0.00 \\
(-0.51)\end{array}$ & $\begin{array}{r}-0.02 \\
(-1.80)\end{array}$ \\
\hline MOM & $\begin{array}{r}0.22 \\
(8.66)\end{array}$ & $\begin{array}{r}0.08 \\
(2.63)\end{array}$ & $\begin{array}{r}0.23 \\
(8.57)\end{array}$ & $\begin{array}{r}0.09 \\
(2.68)\end{array}$ & $\begin{array}{r}0.23 \\
(8.48)\end{array}$ & $\begin{array}{r}0.09 \\
(2.71)\end{array}$ \\
\hline REV & $\begin{array}{r}-2.38 \\
(-8.47)\end{array}$ & $\begin{array}{r}0.66 \\
(1.85)\end{array}$ & $\begin{array}{r}-2.49 \\
(-8.22)\end{array}$ & $\begin{array}{r}0.47 \\
(1.24)\end{array}$ & $\begin{array}{r}-2.21 \\
(-9.13)\end{array}$ & $\begin{array}{r}1.05 \\
(3.31)\end{array}$ \\
\hline
\end{tabular}

들의 매도거래비중 증가에 비해 근소하게 크게 나타난다. 이는 Kong and Park(2013)의 선행연구에서 개인투자자들이 극단적인 수익률을 갖는 종목들에 대한 거래를 늘리던 것과 일치하는 결과이다. 또한 한국 주식시장에서 크기가 작고 고유변동성이 큰 종목들을 개인 투자자들이 많이 거래하고 그로 인해 개인투자자들의 심리가 가격에도 영향을 미친다는 Kang et al.(2013a)의 연구와도 일관된 결과이다. 그 밖에도, 개인투자자들은 직전 1 개월을 제외한 최근 12 개월 동안 오른 종목들에 대해 매도거래대금비중을 늘린 것을 볼 수 있다. 또한, 최근 1 개월 수익률이 높은 종목의 매수거래대금을 유의하게 증가시키고, 매도거래 대금 비중을 유의하게 줄인다. 개인투자자들이 추세역행적(reversal) 거래 행태를 보인다는 Kil et al.(2006) 등의 기존 연구들과 일치한다.

<표 8>의 패널 $\mathrm{B}$ 는 기관투자자의 거래대금비중 변동에 대한 결과를 나타낸다. 기관투자자의 경우에는 개인투자자와는 상반되는 투자행태를 보인다. 기관투자자는 개인투자자들에게 과도한 관심을 받는 일간 승자/패자 종목에 대한 매수 거래를 지난달보다 줄이는 경향이 있다. 일간 승자이면서 패자였던 종목은 그렇지 않은 종목에 비해서 $0.67 \%(\mathrm{t}=13.29)$ 매수 거래 비중을 줄였고, 일간 승자종목에 대해서는 $0.43 \%(\mathrm{t}=9.00)$, 일간 패자종목에 대해서는 $0.89 \%(\mathrm{t}=15.47)$ 매수거래 비중을 줄였다. 절대적인 거래대금이 아닌 전체 거래대금 중 해당 투자자의 거래대금 비중이므로, 개인투자자들이 일간 승자/패자 종목에 대한 거래를 늘리면서 기관투자자의 거래비중이 줄어든다고 해석할 수 있다. 매도거래대금 비중은 패널 $\mathrm{A}$ 의 결과와 마찬가지로 유의한 차이가 나타나지 않는다.

<표 8>의 패널 $\mathrm{C}$ 는 외국인투자자의 거래대금비중 변동에 대한 결과이다. 외국인 투자자 들은 개인투자자들의 많은 관심을 받는 일간 승자/패자 종목들에 대한 거래비중을 현저히 
한국증권학회지 제49권 4호 (2020)

줄이는 것으로 나타난다. 매수거래대금비중과 매도거래대금비중 모두 일간 승자/패자 종목 들에 대해 다른 종목 대비 유의하게 감소시킨 것을 볼 수 있다. 일간 승자이면서 동시에 패자였던 종목에 대해서는 매도거래는 $0.26 \%(\mathrm{t}=3.74)$, 매수거래는 $0.57 \%(\mathrm{t}=6.76)$ 줄이고, 일간 승자종목에 대해서는 매도를 $0.24 \%(\mathrm{t}=4.17)$, 매수를 $0.34 \%(\mathrm{t}=6.12)$, 일간 패자종목에 대해서는 매도를 $0.27 \%(\mathrm{t}=3.22)$, 매수를 $0.69 \%(\mathrm{t}=6.30)$ 줄였다. 외국인투자자들의 거래 행태 중에 눈에 띄는 것은 모멘텀 종목에 대한 매수/매도 거래를 현저히 늘린 것이다. 외국인 투자자의 지분율이 높은 종목에서 모멘텀이 강하게 나타난다는 $\operatorname{Kim}(2018)$ 의 결과와도 일관된 결과이다.

결과를 종합해보면, 일간 승자/패자 종목에 많은 관심을 쏟으며 거래를 늘린 투자자들은 개인투자자로 보인다. 개인투자자들은 하루 중 상위권을 기록한 종목이나 하위권을 기록한 종목에 대해 매수거래비중을 늘린다. 개인투자자들의 과도한 매입은 해당 종목들이 과대 평가되는 데에 기여하게 되고, 이러한 과대평가가 앞서 보았던 일간 승자/패자 효과를 만들어 내는 것으로 해석할 수 있다.

\section{2 현저성(saliency)지수와의 관계}

개인투자자들의 한정된 관심이 일부 극단적인 일간수익률을 기록한 종목들에 과도하게 쏠리면서 일간 승자/패자 포트폴리오가 낮은 미래 수익을 얻는다는 위의 설명이 설득력을 얻으려면, 개인투자자들이 더욱 주식시장에 주의를 집중할 만한 시기에 일간 승자/패자 효과가 강하게 나타나고, 주식시장이 개인투자자들의 이목을 끌지 못하는 시기에 일간 승자 /패자 효과가 약해져야 할 것이다.

이를 확인해보기 위해서, KRU를 따라 현저성 지수를 구성하고, 이 지수의 등락과 $\mathrm{NMB}$ 포트폴리오 수익률의 관계를 살펴본다. 현저성 지수는 일간 승자와 패자의 수익률 차이에 대한 월 평균으로 계산한다. 일간 승자의 수익률과 일간 패자의 수익률 격차가 더 벌어지는

\section{〈표 9〉현저성 지수와 NMB 포트폴리오 수익률}

매월 말, 상위 20위 이내와 하위 20위 이내를 동시에 기록한 종목을 매도하고, 하루도 상위, 하위 20 위 이내에 들지 않은 종목을 매수하는 포트폴리오(NMB 포트폴리오) 수익률을 종속변수로 하고, Fama-French 3요인이나 5요인과 지난달의 현저성 지수(Saliency)를 독립변수로 하는 시계열 회귀분석의 회귀계수와 t값이다. 현저성 지수는 일간 승자와 패자의 수익률 차이에 대한 월 평균으로 계산한다.

\begin{tabular}{lcrrr}
\hline & $(1)$ & \multicolumn{1}{c}{$(2)$} & \multicolumn{1}{c}{$(3)$} & \multicolumn{1}{c}{$(4)$} \\
\hline MKT & $-0.06(-0.54)$ & $-0.02(-0.17)$ & $0.24(2.64)$ & $0.32(3.93)$ \\
HML & $-0.57(-2.05)$ & $-0.53(-1.88)$ & $-0.16(-1.06)$ & $-0.13(-0.89)$ \\
SMB & $-0.90(-3.08)$ & $-0.77(-2.66)$ & $-0.46(-3.30)$ & $-0.30(-2.32)$ \\
RMW & & $0.47(2.76)$ & & $0.59(2.51)$ \\
CMA & & $-0.15(-0.66)$ & & $0.06(0.31)$ \\
Saliency & $0.51(1.88)$ & $0.49(1.90)$ & $0.57(3.09)$ & $0.55(2.96)$ \\
alpha & $3.49(4.45)$ & $3.24(4.26)$ & $4.02(8.05)$ & $3.68(6.92)$ \\
\hline
\end{tabular}


Daily Winners and Losers in the Korean Stock Market

시기에는 투자자들의 이목이 주식시장에 쏠릴 것이고, 수익률 격차가 줄어드는 시기에는 투자자들의 관심이 멀어질 것이라고 예상한다. 〈표 9>는 NMB 포트폴리오 수익률을 종속 변수로 하고, 알려진 가격 요인(Fama-French 3요인과 Fama-French 5요인)과 지난 달의 현저성지수를 독립변수로 하는 시계열 회귀분석의 회귀 계수를 나타낸다. $\mathrm{NMB}$ 포트폴리오의 조정수익률에 대한 현저성지수의 예측회귀분석인 셈이다.

<표 9>의 결과는 예상한 바와 같이 현저성지수가 증가한 뒤, NMB 포트폴리오 수익률이 더 커지는 것을 확인할 수 있다. 일간 수익률 격차가 증가하는 경우, 투자자들이 일간 승자/ 패자 종목에 더 많은 관심을 기울이게 되어 과대평가가 더 심하게 된다는 것을 시사한다.

\section{6. 결론}

본 연구는 $\mathrm{KRU}$ 에 따라 국내 주식 시장에 일간 승자/패자 효과가 있는지 분석하고, 일간 승자/패자 효과가 고유변동성 이상현상이나 MAX 효과를 설명할 수 있는지 살펴본다. 본 연구의 실증 분석 결과는 한국 주식시장의 일간 승자/패자 효과 존재를 지지하며, $\mathrm{KRU}$ 와 마찬가지로 일간 승자종목과 패자종목에 쏠리는 과도한 관심과 그에 따른 과대평가를 그 원인으로 지목하고 있다.

효율적 시장가설이 성립하기 위해서는 투자자들이 무한한 인지적 자원을 갖고 이용 가능한 모든 정보를 합리적으로 활용하여 처리하며, 주식 가격은 이러한 모든 정보를 즉각적으로 반영해야 한다. 하지만, 투자자의 관심은 한정된 자원이고, 따라서 많은 투자자들은 모든 투자자산에 대해 합리적으로 분석하여 투자하는 것이 불가능하다. 따라서 눈에 띄는 정보에 관심이 쏠리고, 주의를 끄는 종목과 정보 내에서 투자 의사결정을 내릴 수 밖에 없다. 특히 이런 제약은 개인투자자에게 강하게 나타난다. 본 연구의 분석에 따르면, 개인투자자들은 일간수익률이 아주 높거나 아주 낮은 극소수의 종목에 관심을 쏟는 경향이 있으며, 이런 종목들의 매수 비중을 늘리는 것으로 나타난다. 일간 승자나 패자 종목은 개인투자자들의 과도한 매수로 인해 과도한 가격 상승과 낮은 미래수익률을 얻게 된다. 이러한 현상은 위험에 대한 보상으로는 설명이 되지 않는다. 뿐만 아니라, 투자자들의 복권 성향 주식 선호로 인해 발생하는 것으로 여겨졌던 고유변동성 이상현상이나 MAX 효과가 개인투자자들의 집중적인 관심을 받는 일간 승자나 패자종목에서만 강하게 나타난다. 이와 같은 실증결과는 고유변동성 이상현상과 MAX 효과가 나타나는 근본 원인 중 하나가 개인투자자들의 눈에 띄는 일간 승자/패자 종목에 대한 과도한 관심일 수 있음을 시사한다.

본 연구의 결과는 미디어에서 자주 노출되는 종목 정보가 시장 가격과 효율성에 영향을 줄 수 있음을 시사한다. 이는 미디어가 제공하는 정보가 투자자 간 정보비대칭을 해소할 수도 있으나, 반대로 시장의 효율성을 저하시키는 결과를 초래할 수도 있음을 의미한다. 
한국증권학회지 제49권 4호 (2020)

\section{References}

Ang, A., R. J. Hodrick, Y. Xing, and X. Zhang, 2006, The Cross-Section of Volatility and Expected Returns, Journal of Finance, Vol. 61 (1), pp. 259-299.

Bali, T. G., N. Cakici, and R. F. Whitelaw, 2011, Maxing Out: Stocks as Lotteries and the Cross-Section of Expected Returns, Journal of Financial Economics, Vol. 99 (2), pp. 427-446.

Barillas, F., and J. Shanken, 2017, Which alpha?, The Review of Financial Studies, Vol. 30 (4), pp. 1316-1338.

Eom, Y., 2013, Momentum Profits and Firm, Korean Journal of Financial Studies, Vol. 42 (5), pp. 901-927.

Fama, E. F., and K. R. French, 1999, Common Risk Factors in the Returns on Stocks and Bonds, Journal of Financial Economics, Vol. 33 (1), pp. 3-56.

Fama, E. F., and K. R. French, 2015, A five-factor asset pricing model, Journal of Financial Economics, Vol. 116, pp. 1-22.

Fama, E. F., and K. R. French, 2018, Choosing factors, Journal of Financial Economics, Vol. 128 (2), pp. 234-252.

Fama, E. F., and J. D. MacBeth, 1973,Risk, Return and Equilibrium: Empirical Tests, Journal of Political Economy, Vol. 81 (3), pp. 607-636.

Jang, J, 2017, Price Momentum Anomaly Revisited: Evidence in the Korean Stock Market, Asian Review of Financial Research, Vol. 30 (3), pp. 317-359.

Jegadeesh, N., and S. Titman, 1993, Returns to Buying Winners and Selling Losers: Implications for Stock Market Efficiency, Journal of Finance, Vol. 48 (1), pp. 65-91.

Kang, J., K. Kwon, and M. Sim, 2013a, Retail Investor Sentiment and Stock Returns, The Korean Journal of Financial Management, Vol. 30 (3), pp. 35-68.

Kang, J., and M. Sim, 2014, Lottery-Like Stocks and the Cross-Section of Expected Stock Returns in the Korean Stock Market, Asian Review of Financial Research, Vol. 27 (2), pp. $297-332$.

Kang, J., D. Lee, C. Lee, and J. Choi, 2013b, A Construction of the Korean Stock Database and Its Applications, Asian Review of Financial Research, Vol. 26 (3), pp. 311-351.

Kil, J., N. Kim, and Y. Son, 2006, The Impact of the Investors` Trading Behavior on the Return and the Volatility in the Recent Korean Stock Market, Korean Journal of Financial Studies, Vol. 35 (3), pp. 77-106.

Kim, K., 2018, Analysis of Relationship between Price Momentum and Investor Types' Trade Imbalance, Journal of Money \& Finance, Vol. 32 (4), pp. 37-74. 
Daily Winners and Losers in the Korean Stock Market

Kim, T., and Y. Byun, 2011, The Relationship between Idiosyncratic Volatility and Expected Returns in the Korea Stock Markets, Korean Journal of Financial Studies, Vol. 40 (3), pp. 525-550.

Kong, O., and D. Park, 2013, The Impact of Attention Effect on the Buying Behavior of Investors in the Korea Stock Market, The Korean Journal of Financial Engineering, Vol. 12 (3), pp. 75-98.

Kumar, A., 2009. Who Gambles in the Stock Market?, The Journal of Finance, Vol. 64 (4), pp. 1889-1933.

Kumar, A., S. Ruenzi, and M. Urgeheuer, Daily Winners and Losers, Working Paper, 2020. https://ssrn.com/abstract=2931545.

Lee, J., Y. Lee, and J. Chae, 2019, Investor Attention and Expected Return, Journal of Derivatives and Quantitative Studies, Vol. 27 (1), pp. 49-83. 